\title{
Grasslands and Open Savannas of the Dry Chaco
}

Pedro D Fernández, Instituto de Investigación Animal del Chaco Semiárido, Instituto Nacional de Tecnología Agropecuaria (INTA), Tucumán, Argentina; Instituto de Ecología Regional, CONICET, Universidad Nacional de Tucumán, Tucumán, Argentina

Baumann Matthias, Geography Department, Humboldt-University Berlin, Berlin, Germany

Baldi Germán, Instituto de Matemática Aplicada San Luis, Universidad Nacional de San Luis \& CONICET, San Luis, Argentina

Banegas R Natalia, Instituto de Investigación Animal del Chaco Semiárido, Instituto Nacional de Tecnología Agropecuaria (INTA), Tucumán, Argentina

Bravo Sandra, Instituto de Silvicultura y manejo de Bosques, Universidad Nacional de Santiago del Estero, Santiago del Estero, Argentina Gasparri N Ignacio, Instituto de Ecología Regional, CONICET, Universidad Nacional de Tucumán, Tucumán, Argentina; Facultad de Ciencias Naturales, Universidad Nacional de Tucumán, Tucumán, Argentina

Lucherini Mauro, GECM, Instituto de Ciencias Biológicas y Biomédicas del Sur, CONICET_UNS, Bahía Blanca, Argentina

Marinaro Sofia and Nanni A Sofia, Instituto de Ecología Regional, CONICET, Universidad Nacional de Tucumán, Tucumán, Argentina

José A Nasca, Instituto de Investigación Animal del Chaco Semiárido, Instituto Nacional de Tecnología Agropecuaria (INTA), Tucumán, Argentina

Tessi Torcuato, Grupo de Recursos Forrajeros, Área de Producción Animal, INTA EEA Manfredi., Córdoba, Argentina

Grau H Ricardo, Instituto de Ecología Regional, CONICET, Universidad Nacional de Tucumán, Tucumán, Argentina; Facultad de Ciencias Naturales, Universidad Nacional de Tucumán, UNT, Tucumán, Argentina

(C) 2019 Elsevier Inc. All rights reserved.

Introduction

Natural Grassland and Savannas Typologies and Distribution

Historic Land-Use Changes Affected Dry Chaco Grassland Present Day Distribution

Environmental Characteristics

Climate and Soils

Floristic Composition and Diversity

Ecosystem Management and Properties

Fire Regime

Assessing the Role of Natural Grasslands in Cattle Grazing, and Exploring Sustainable Intensification Opportunities

Cattle Grazing in Natural Grasslands and Savannas

Assessing Potential for Cattle Intensification

Livestock-Wildlife Interactions

Conservation and Representation in Protected Areas

Future Research and Conclusions

References

\begin{abstract}
The Dry Chaco is mostly known as a forested ecosystem. However it includes natural grasslands, savannas, scrublands, and wetlands. With one of the highest global deforestation rates in the last two decades and only $12 \%$ of the area protected, the concern about land-use change in this ecoregion has raised exponentially; but conservation initiatives developed in last years almost exclusively targeted forests whereas natural grasslands and savannas remain as neglected ecosystem within scientific and governmental agendas. While currently the distribution of natural grassland and savanna area encompasses over $20,000 \mathrm{~km}^{2}$, historical records and spatial models indicate that natural grassland and savannas were more widespread in pre-European era. Two main reasons drove this reduction in natural grasslands and savannas: woody encroachment by fire suppression and overgrazing, and conversion to agriculture and implanted pastures. In this article, through a combination of analyzes and bibliographic revisions, we describe biotic and abiotic components of natural grassland and savannas of the Dry Chaco. We also present the current distribution and conservation status of these ecosystems, and describe the process of change and the ecological consequences for biogeochemical cycles and biologic interactions. To provide basis for management, we estimate current grazing stocking rates on natural grasslands and savannas of Argentine Dry Chaco and we propose an alternative approach to sustainably intensify the use of these ecosystems and improve cattle rancher livelihoods. Despite the existent knowledge about natural grasslands and savannas in the region, we believe that is necessary to motivate the scientific community and national institutions to increase efforts to reconcile the restoration and conservation of these particular rangelands.
\end{abstract}

\section{Introduction}

The Dry Chaco is, for the most part, a vast sedimentary plain, essentially modeled by the action of rivers that cross it in a northwestsoutheast direction. Expanding from 33.8 to $22^{\circ} \mathrm{S}$ and from 67.5 to $59.2^{\circ} \mathrm{W}$, this ecoregion is mostly known for its forests. However, 
it includes natural grasslands, savannas, scrublands, and wetlands (Adamoli et al., 1990; Navarro et al., 2006). With one of the highest global deforestation rates in the last two decades (Baumann et al., 2016; Grau et al., 2005), and only 12\% of the area protected, the concern about land-use change has raised exponentially, and some governmental initiatives for conservation has been taken, such as the promotion of a national forest conservation law in Argentina. However, agriculture does not only expand into forests but also into natural grasslands and savannas with less energy to plow up and convert them, representing a major conservation challenge for the scientific and governmental agendas (Grau et al., 2014).

Albeit the introduction of European livestock into South America started in the 16th century (Bishko, 1952; Kunst et al., 2003), it was not until the beginning of the 20th century that cattle ranching began to spread into the Chaco rangelands (Adamoli et al., 1990). By 1930, the excessive stocking rate had degraded the herbaceous forage resources, and started its own decay (Morello and Saravia Toledo, 1959). As with other semi-arid regions of the world (Smith, 1899; Griffiths, 1904; Wooton, 1908), such over abundant cattle for many years favored scrubland expansion while herbaceous cover and productivity decreased in natural grasslands and savannas.

Domestic livestock-driven degradation of semiarid rangelands remains controversial in climates with high annual rainfall variability (von Wehrden et al., 2012) as some areas of the Dry Chaco. But, a sum of evidence, including historic registers, town names, and distributions models, indicates that the extension of natural grasslands and savannas was much larger prior to domestic livestock expansion in the early 20th century (Grau et al., 2014; Kunst et al., 2003). The degradation process of natural grasslands could have been reinforced by the sedentary character of the main cattle grazing production system in that period: the "puestos," in which cattle is managed centered around a water source (commonly near the center of ranch) shaping a 70-150 km² "piospheres," and without transhumance in periods of fodder shortage (Adamoli et al., 1990) contributing to the overgrazing process.

There are still many information gaps at different scales in natural grasslands and savannas of the Dry Chaco. For example, we do not know the pre-European distribution of these natural rangelands, since such knowledge would require detailed paleo-ecological research inexistent to date. Neither the current state of degradation, nor even knowledge of the physiognomy and distribution of the "old-growth" grasslands (see Veldman et al., 2015), which could represent the most valuable information in terms of conservation, is known. The role of these ecosystems in biological interactions, biogeochemical cycles and the provision of ecosystem services has been superficially explored to date. The sum of these information gaps represents the first obstacle to determine conservation areas and apply restoration practices in these natural areas with the least impacts on the well-being of local communities.

Currently Dry Chaco presents multiple challenges, with large undeveloped reserves of natural resources (principally native forest), widespread poverty, extensive livestock supporting the subsistence of thousands of small farmers, and one of the most active agricultural frontiers with the associated conflicts for land tenure, nature conservation, and regional development. This chapter revises the existent knowledge about natural grasslands and savannas in the region, as a way to motivate the scientific community to increase efforts in understand these ecosystems to reconcile the restoration, conservation and sustainable development. Although we aim at addressing the entire ecoregion in this article, the discussed analyses mostly involve the Argentine Dry Chaco (which encompasses $69 \%$ of the region), due to the paucity of information for the Bolivian and Paraguayan areas.

Specifically, in this article we (1) describe the current distribution and typologies of grasslands of the Dry Chaco; (2) discuss the recent and historical drivers that resulted in present-day patterns; (3) describe the soils, climate, and floristic composition of natural savannas; (4) discuss the current drivers of natural grassland transformations, their management, and their impact in ecosystem services; (5) estimate the cattle stock grazing for the Argentinean part of the region to explore opportunities for sustainable intensification to conserve these ecosystems; and (6) describe the role of native grasslands for biodiversity conservation in relation to the current conservation status of the region.

\section{Natural Grassland and Savannas Typologies and Distribution}

Using Landsat TM and ETM + image composites and identifying different spectral signatures (Baumann et al., 2016) we mapped natural grasslands in the entire Dry Chaco (i.e., including Argentina, Bolivia and Paraguay) (Fig. 1). However, it was not possible to discriminate among the different types mentioned below, as well as to discriminated old-growth natural grassland and savannas (Veldman et al., 2015) from grasslands generated in post agriculture early successional stages of vegetation. Based on this analysis, we estimate that natural grasslands area extends over 20,369 $\mathrm{km}^{2}$ (Table 1 ).

The majority of natural grasslands and savannas are located in the southeast limit of the region, towards drier and colder conditions in Cordoba, and southern Santiago del Estero provinces, representing near $60 \%$ of the total. In Bolivia and Paraguay, grasslands are more scattered than in Argentina. In the west of Santa Cruz (Bolivia) exist a concentration of edaphic natural grasslands associated with sandy soils representing near $10 \%$ of the total area of the region.

We briefly describe four main types of grasslands and savannas of the Dry Chaco region and mapped the distribution of natural grassland and savannas for the entire area (Fig. 1). More detailed descriptions of vegetation physiognomies can be found for Bolivian Chaco (Navarro and Fuentes, 1999), Paraguayan Chaco (Navarro et al., 2006), and for the Argentinean Dry Chaco region (Morello et al., 2013). Based on these, we identify the following typologies:

1. Grassland and savannas located in lowlands close to rivers and permanent waters bodies; typically with poorly drained clay, high water table and recurrent flooding, often with-high salt content. These grasslands and savannas are mainly concentrated in the Dulce river basin or wetlands as Bañado del Izozog or Bañado de la Estrella. These areas are not suitable for agriculture and are 


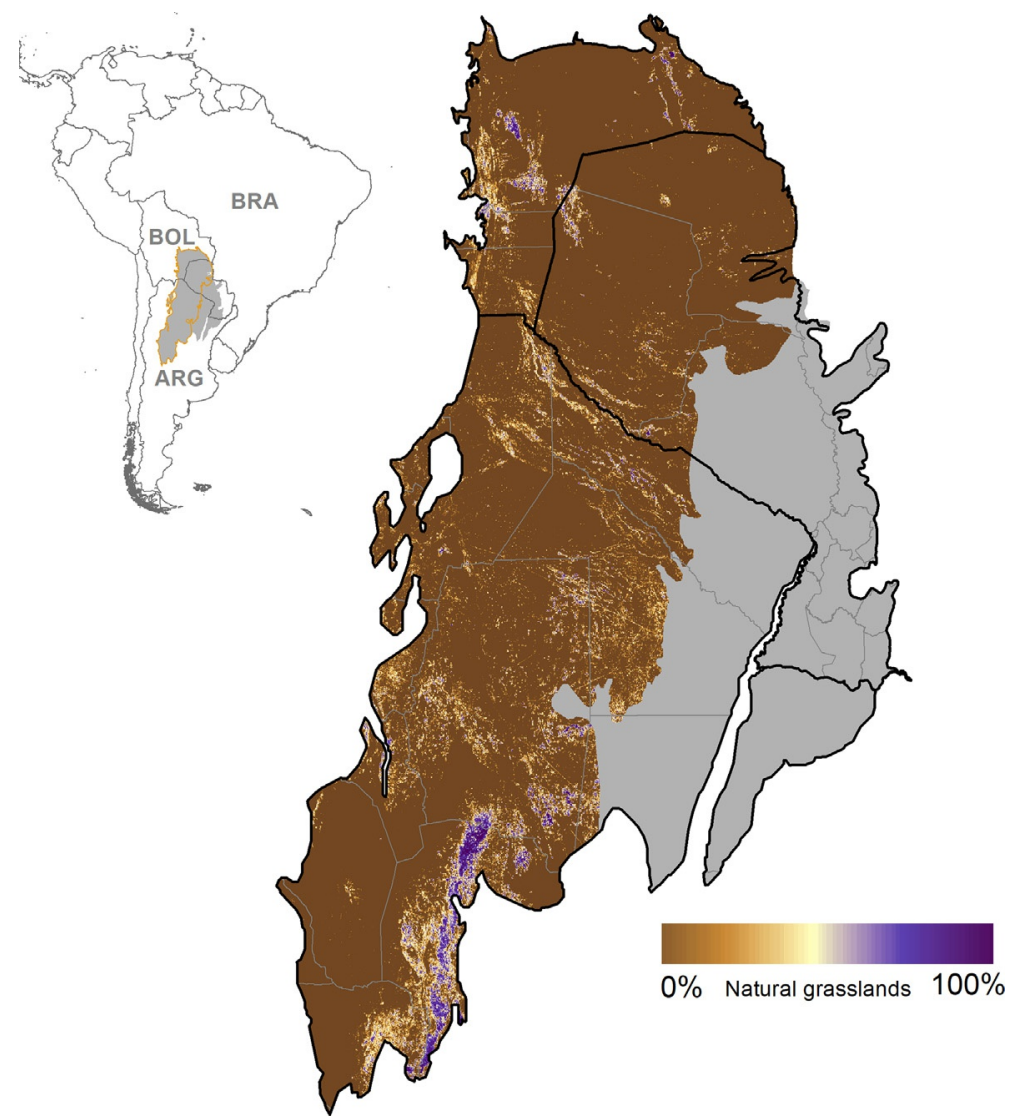

Fig. 1 Current distribution of natural grasslands and savannas in the Dry Chaco region (Argentina, Bolivia and Paraguay). In gray, the ecoregion of Humid Chaco.

Table 1 Estimated extension of natural grasslands by first order national subdivision for 2013.

\begin{tabular}{|c|c|c|c|}
\hline Country & First order national subdivision & Natural grassland area $\left(\mathrm{km}^{2}\right)$ & Relative extension (\%) \\
\hline \multirow[t]{12}{*}{ Argentina $16,595 \mathrm{~km}^{2}(81.5 \%)$} & Córdoba & 7040 & 34.6 \\
\hline & Santiago del Estero & 3945 & 19.4 \\
\hline & Chaco & 1228 & 6.0 \\
\hline & Salta & 1134 & 5.6 \\
\hline & San Luis & 1049 & 5.1 \\
\hline & Formosa & 829 & 4.1 \\
\hline & Catamarca & 511 & 2.5 \\
\hline & Tucuman & 367 & 1.8 \\
\hline & Santa Fe & 337 & 1.6 \\
\hline & Jujuy & 78 & 0.4 \\
\hline & La Rioja & 74 & 0.4 \\
\hline & San Juan & 2 & 0.0 \\
\hline \multirow[t]{3}{*}{ Bolivia 2548 km² (12.5\%) } & Santa Cruz & 2033 & 10 \\
\hline & Chuquisaca & 261 & 1.2 \\
\hline & Tarija & 253 & 1.2 \\
\hline \multirow[t]{3}{*}{ Paraguay 1226 km² $(6 \%)^{2}$} & Boquerón & 862 & 4.2 \\
\hline & Alto Paraguay & 182 & 0.9 \\
\hline & Presidente Hayes & 182 & 0.9 \\
\hline Total & & 20,368 & \\
\hline
\end{tabular}

mainly used by extensive traditional grazing livestock. In the area comprising northern Argentina and southwestern Paraguay and southern Bolivia, they include palm savannas dominated by Trithrinax schizophylla and Copernicia alba as tree components (Fig. 2).

2. Edaphic grassland and savannas. They are situated in low fertility sandy soils associated with ancient river meanders ("paleocauces"). They are found in the northwest of the Bolivian Chaco; and Argentina (center of Santiago del Estero province) and the 


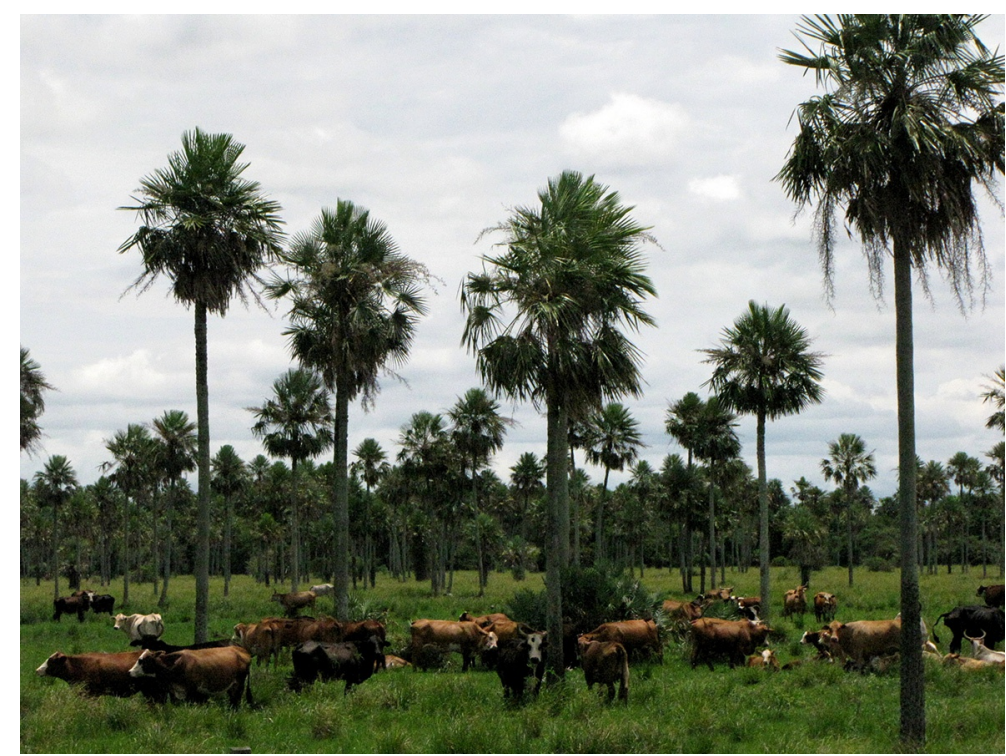

Fig. 2 Poor drained and regular flooded Savanna with a Copernicia palm woody component (Formosa province, Argentina). Photo by courtesy of Alejandro Brown.

area of influence of the Juramento, Bermejo and Pilcomayo rivers (Salta and Formosa provinces). They are also used mostly for low-intensity grazing. Recurrent fires maintain the herbaceous cover of grasslands dominated by Elionurus muticus, with isolated trees of the genera Prosopis ("Algarrobos") and Aspidosperma ("Quebrachos blancos").

3. Mesic grasslands and savannas. Commonly located in deep and fertile soils. They are concentrated in the east of Santiago del Estero province and west of Chaco provinces, Argentina. To persist, they need recurrent fires generating in a positive feedback associated with high flammability and post-fire resprouting capacity of the dominant grasses. Given their high agriculture potential, most of them have been converted into croplands and implanted pastures.

4. Montane grasslands located in the south and western borders of the ecoregion (Cordoba and San Luis province in Argentina; Sierra San Miguel in Bolivia). Commonly dominated by Festuca hieronymi, they can alternate with short grasslands in shallow rocky soils patches. These grasslands are used in extensive cattle ranching, as topography limits croplands in these fertile soils. In the Cordoba provinces they have also been replaced for pine plantations in extensive areas.

\section{Historic Land-Use Changes Affected Dry Chaco Grassland Present Day Distribution}

In 1950, the geographer Carl Sauer claimed that all the world's grasslands had coevolved with humans and fire for some 200,000 years (Sayre et al., 2017). In South America, before the expansion of European land uses, descriptions indicate regular use of fire by indigenous communities to hunt and to preserve open areas (Jolis, 1972).

The Chaco was not the exception, and indigenous uses likely persisted for most the 19th century, since the region was mostly outside the colonial influence (Métraux, 1946). However, with the introduction of cattle following the colonization by "Criollos" people in Argentina and Mennonites in Paraguay and Bolivia, a process of overgrazing and depletion of fine fuel in grasslands changed fire regimes and reduced herbaceous cover, and shrub encroachment spread over natural grasslands and savannas. Such processes took place mostly from 1890 to 1950, according to different authors (de Maurice et al., 1919; Muello, 1926; Morello and Saravia Toledo, 1959). The restoration of herbaceous productivity began to be done through the implantation of exotic and more productive pastures. For example, in the early 1950s, Robert Unruh, an agronomy engineer, introduced the first exotic grass (Pennisetumciliaris) in the Paraguayan Dry Chaco, starting the expansion of implanted pastures in the region (Glatzle, 1999). In Bolivia, the British Mission in Tropical Agriculture started the shift from natural grasslands to implanted pastures, introducing many of the most successful cultivated pastures in the 1970s (Killeen et al., 2008). In the montane grasslands of Cordoba natural grasslands have been used for cattle ranching for at least 400 years (Díaz et al., 1994), with well-documented processes of overgrazing and soil erosion (Menghi et al., 1978).

The historical importance of natural grasslands and savannas in the Dry Chaco has been analyzed particularly for northern Argentina by Grau et al. (2014), combining approaches as historical assessments, environmental modeling, and toponyms that refer to natural grassland. Such analyses consistently shows that, in the past, many sectors of the northern Argentine Dry Chaco (mainly towards the limit between Formosa and Salta provinces and the east sector, covering areas of Chaco, Formosa and Santiago del Estero provinces) likely included extensive areas of natural grasslands and savannas as part of the pre European landscape. 


\section{Environmental Characteristics}

\section{Climate and Soils}

In the Dry Chaco, the presence of pronounced climatic gradients together with heterogeneous geomorphological characteristics, generate a diversity of environments reflected in vegetation physiognomies (dry and flooded savannas, estuaries, marshes, salters, and a great extension and diversity of forests and shrublands) (Adamoli et al., 1990). Despite such heterogeneity, the Dry Chaco plains host one of the largest global reserves of fertile soils that are still uncultivated (Lambin et al., 2013), which in combination with flat terrain and low population density facilitates the expansion of large-scale mechanized agriculture.

In Koppen's classification for South America (Peel et al. 2007), the Dry Chaco region is included within three climatic regions: subtropical humid, warm semiarid, and cold semiarid. Subtropical humid host the South American "heat pole," defined as the territory where absolute maximums exceed $47^{\circ} \mathrm{C}$ (e.g., Rivadavia district in Argentina or $44{ }^{\circ} \mathrm{C}$ in Filadelfia department in Paraguay). In the southern portion of the region, mean annual temperatures range from $23{ }^{\circ} \mathrm{C}$ to $18{ }^{\circ} \mathrm{C}$ (in La Rioja and San Luis), with absolute minimum temperatures as low as $-10^{\circ} \mathrm{C} /-15^{\circ} \mathrm{C}(\mathrm{GTZ}, 2006$ Atlas Gran Chaco). Inter-annual rainfall is highly variable and occurs mainly during the warmer months, and about $80 \%$ is concentrated between October and March (Capitanelli, 1979). However, in years during the "El niño" phase of the climatic southern oscillation, autumns and winters tend to be rainy (Glatzle, 1999). Rainfall ranges from $800 \mathrm{~mm}$ to $200-300 \mathrm{~mm}$ per year. The wettest areas are located in eastern sector, close to the Humid Chaco, and in the western sector in transition with the Yungas ecoregion; and driest areas are located towards the south, in San Luis and La Rioja provinces (Boletta, 1988).

All the permanent fluvial systems, such as Pilcomayo, Bermejo, Juramento-Salado and Salí-Dulce, are allochthonous; i.e., they do not receive affluent in their journey through the ecoregion (Burkart et al., 1999). There are at least two important intermittent rivers for the subfluvial flows, the Del Valle and the Dorado. With the exception of these rivers, permanent water bodies are strange in the Dry Chaco, constituting the principal limitation to rural population and livestock (Glatzle, 1999). The shallow subterranean water is commonly briny, for which rainwater harvesting constitutes a key technology in the region (Magliano et al., 2015).

The Dry Chaco region lies in a structural environment of sedimentary basin, and as a unit of relief it transcends regional boundaries and extends between the crystalline massif of Brasilia, and the Andes mountain range. The behavior of the sedimentary basin is governed by a tendency to sink, at very slow speeds, but continued from the Paleozoic until today which has led it to remain depressed with respect to its peripheral areas, and to receive as sediments the eroded materials of those. With exceptions of mountains in the south and northwestern borders (including mountain ranges up to 2000 m.a.s.l.), topography is mostly flat, and elevation rarely exceeds 200 m.a.s.l., in a gentle regional slope from northwest to southeast (Moretti et al., 2018). In the region there is a diversity of parental materials due to different areas of contribution and sedimentary processes, which determined the composition and particle size in soils. However, the dominant materials are fluvial sediments, and to a lesser extent area, lacustrine and eolian (Moretti et al., 2018).

The dominant order soils are Mollisols and Alfisols; and to a lesser extent, Entisol, Inceptisol and Aridisol (Moretti et al., 2018; SAGyP-INTA, 1990). A huge proportion of soils has moderate to well-developed profiles. Mollisols are mostly developed from loess sediments. They have thick surface A horizons rich in organic matter, and show varying degrees of development in accordance with drainage conditions and their moisture regimen: the presence of an argillic subsurface horizons (Bt) (Argiustoll or Argiudoll) in the humid areas, but in slightly drier areas dominate Haplustoll (A- AC-C or incipient $\mathrm{Bw}$ ). In this situation accumulations of calcium carbonates in depth are common (Ck). The Alfisols are present in the plains, and they were developed from fine-textured materials, generally associated with the original forest and shrub vegetation. They are deep soils with thick clayey Bt horizons. In general, the soils of the region have high percentages of base saturation, neutral to basic $\mathrm{pH}$ and medium values of CEC, and the mottles and gley features are common.

\section{Floristic Composition and Diversity}

In poorly drained and regularly flooded grassland and savannas, the woody stratum is commonly dominated by the presences of Prosopis ruscifolia, finding also species such as Bulnesia bonariensis or Bulnesia sarmientoi, Capparis retusa or Capparis tweddiana and Acacia cavens or Acacia monacantha, Loncocharpus fluvialis, Tabebuia nodosa, Parkinsonia aculeata and palms such as Trithrinax schizophylla or Copernicia alba (Fig. 2). The herbaceous stratum is dominated by the grasses Cenchrus pilcomayensis, Schizachyrium condensatus, Sporobolus phleoides and Heteropogon contortus; and other common herbaceous species of the genus Eupatorium (Asteraceae) and Solanum (Solanaceae). Halophytic vegetation appears in soils with high level of salt, such as the floodplain of the lower Dulce river, and it is mainly represented by Allenrolfea vaginata, Atriplex spp., Stetsonia coryne, Prosopis ruscifolia, Maytenus vitis-idea, and Spartina argentinensis.

In edaphic natural grassland and savannas (Fig. 3), grasses are dominated by Elionorus muticus (syn. Aibe, Espartillo or Paja amarga), which can reach $30-90 \%$ of grass cover. These species are very flammable, with terpenes in foliage that reach maximum concentration in spring, in coincidence with environmental conditions predisposing to fires in the region (Bravo et al., 2001a; Hess et al., 2007). Bucher (1982) defined these landscapes as pyrogenic savannas. Pennisetum frutescens, Heteropogon contortus, Pappophorum pappiferum, Digitaria californica, Schizachyrium tenerum, Trichloris pluriflora, Bothriochloa laguroides are other grass species of pyrogenic savannas, and the later three have high tolerance to fires due to survival of underground parts and high re-sprouting capacity. Some herbaceous Fabaceae species, such as Rynchosia senna and Indigofera parodiana, enhance grassland forage potential due to nitrogen content. Asteraceae species, such as Bacharis pingraea and Baccharis trimera are common in E. muticus savannas; and fires 


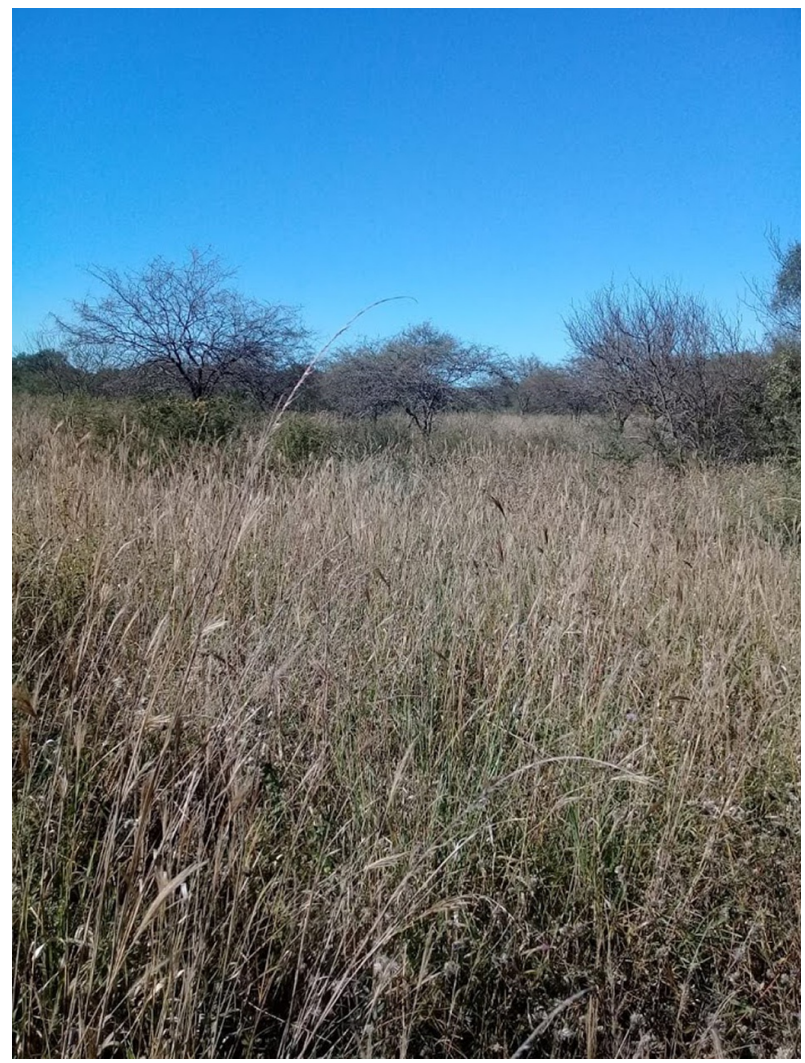

Fig. 3 Edaphic savanna in lowlands of Dry Chaco (Northwest of Santiago del Estero, Argentina). Photo by courtesy of Sandra Bravo.

can promote the recruitment of rare species, such as Dimerostemma hieronymi. Rhizomatous and perennial species vegetate successfully in these disturbed environments, reestablishing through underground organs. Lippia turbinata, Aloysia gratissima, and Lantana sp. are Verbenaceae species containing aromatic components that can feedback fire recurrence, increasing grassland flammability. Isolated trees of Aspidosperma quebracho-blanco, Prosopis nigra, Prosopis kuntzei and small shrubby patches of Vachellia aroma, Schinus bumeloides, Schinus fasciculatus and Celtis ehrenbergiana are scattered across these savannas. In Bolivia appear Schinopsis cornuta trees.

In mesic grassland with deep and fertile soils (Fig. 4), herbaceous strata are dominated by the Poaceae species Trichloris crinita, Trichloris pluriflora, Gouinia paraguariensis, Gouinia latifolia, Setaria argentina, Setaria gracilis, Digitaria sanguinalis, Pappophorum pappiferum, Pappophorum mucronulatum (Herrera et al., 2003). Acacia caven, Senegalia gilliesii, Larrea divaricata, Celtis ehrenbergiana and Condalia microphylla are the most common woody invaders in these grasslands (Cabido et al., 2018).

In the montane environments, pure grasslands are rare and dominated by $\mathrm{C} 4$ species below 1000 m.a.s.l. Above this elevation ground cover dominance turns towards C3 species up to close to 2000 m.a.s.l. (Cabido et al., 1997, 1998) and grasslands become a common physiognomy. As altitude increases and temperature decreases, grasses of the genera Nassella and Festuca take over the landscape from 1000 to 1850 m.a.s.l. The most common physiognomy is Festuca hieronymi tussock communities that alternate with short grasslands and grazing lawns (Fig. 5). Short grasslands are found in shallow, rocky and dry soil patches. Grasses Nassella spp., Aristida spegazzinii, Schizachyrium spicatum, Eustachys retusa and forbs Dichondra sericea, Margyricarpus pinnatus, Acalypha communis, Baccharis spp., Galactia glaucophylla, Lucilia acutifolia are common. Grazing lawns are found in terrain concavities with poor drainage. These are the flattest areas in the landscape and are crossed by permanent or temporal water courses, both factors that improves habitat condition for cattle, increasing grazing pressure. Paspalum notatum, P. dilatatum, Steinchis mahians, Sporobolus indicus, Axonopus fissifolius, Cyperus spp., Bulbostylis spp. and Trifolium repens thrive here. Short grasslands and lawns are found in the extremes of both soil depth and soil moisture gradients, in between the landscape is dominated by Festuca hieronymi tussocks, accompanied by climbing or shade tolerant species such as Cologania broussonetii, Tragia geraniifolia, Oxalis conorrhiza, Chevreulia sarmentosa, Pfaffia gnaphalioides, Eryngium horridum and Dichondra microcalyx among others.

\section{Ecosystem Management and Properties}

Rangelands provide multiple ecosystems services, but only few of them have market value (Sala and Paruelo, 1997). Further, the demands and perceptions on these ecosystem services vary among stakeholders (Lamarque et al., 2011), and geographical regions (Anadon et al., 2014). In the case of the Chaco's ranchers, the use of herbaceous biomass as fodder constitutes the main demand. 


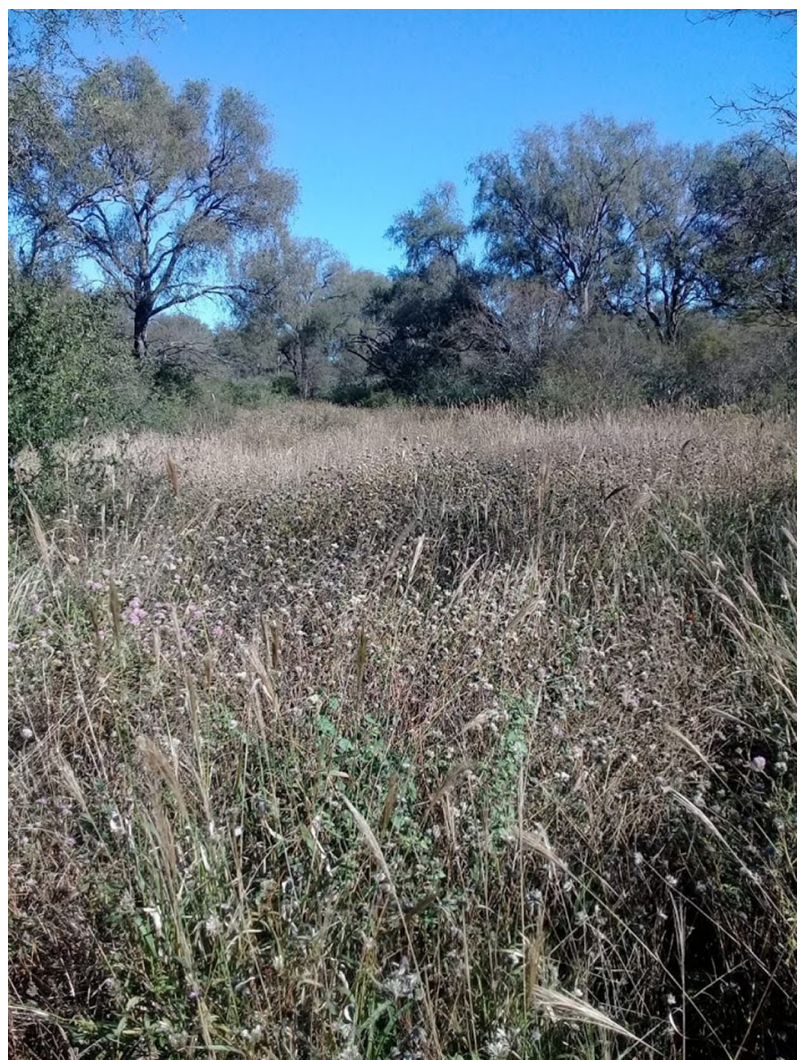

Fig. 4 Mesic grassland in deep and fertile soil (Northwest of Santiago del Estero province, Argentina). Photo by courtesy of Sandra Bravo.

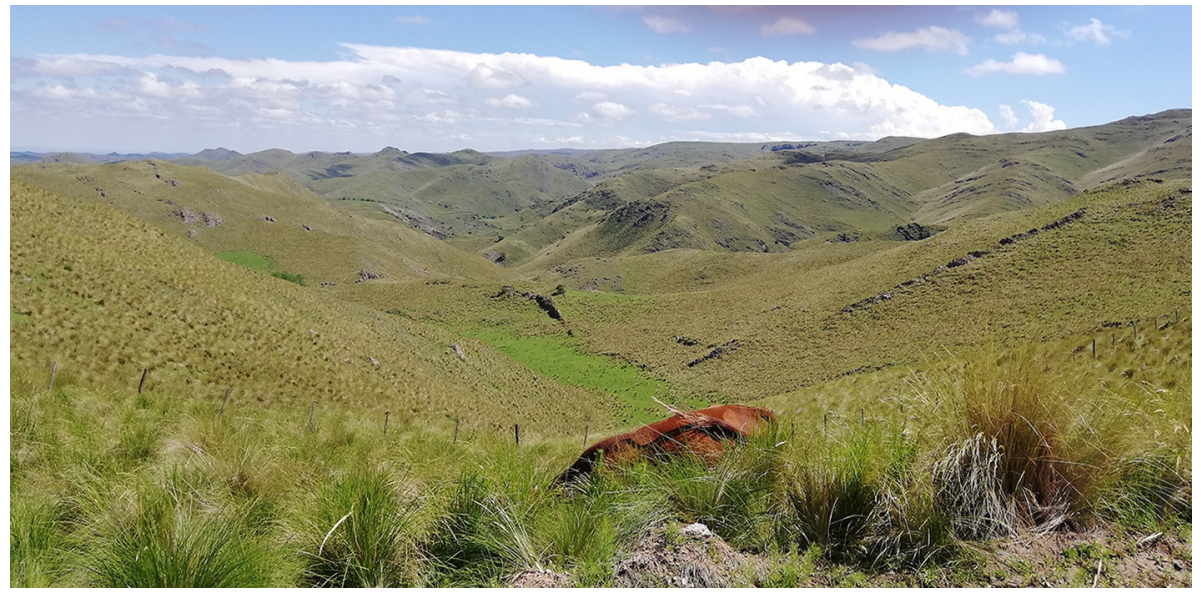

Fig. 5 Montane grassland dominated by Festuca hieronymi (Northern Cordoba province, Argentina, 1600 m.a.s.I.). Photo by courtesy of Torcuato Tessi.

When agriculture is possible, as in the mesic and mountain natural grasslands, the major threat to such ecosystems has been an accelerated conversion to crops in mesic grasslands or to pine plantations in mountain grasslands. However, most natural grassland and savannas of the Dry Chaco have undergone two major transformation processes: the degradation by overgrazing and the increasing of productivity with exotic grasses. Both processes probably have been propelled by the demand for herbaceous forage and resulted in changes in ecosystem structure and function. Below, we discuss the patterns emerging from the local literature, and contrast them with global patterns described in international rangeland literature. In addition, we highlight regional information gaps and outline an avenue to restoration of these singular ecosystems.

In natural grasslands and savannas of the Dry Chaco, differences in vegetation structure and functionality are driven by hierarchically organized factors, including climate, topography, soil development and textures. However, these differences are blurred by past vegetation management, principally carrying capacity and disturbances regimes (Kunst et al., 2006). 


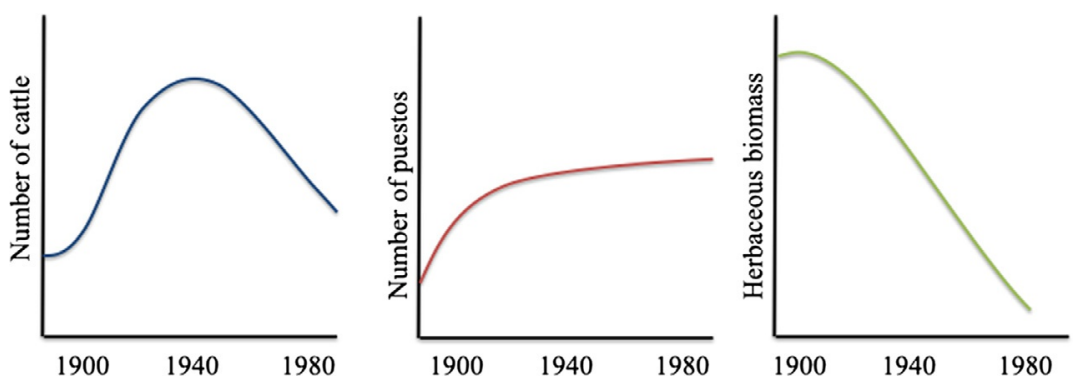

Fig. 6 Cattle, puestos and herbaceous biomass dynamic during the 20th century. Adapted from Adamoli, J., Sennhauser, E., Acero, J.M., Rescia A., 1990. Stress and disturbance: Vegetation dynamics in the Dry Chaco region of Argentina. Journal of Biogeography 17, 147-156.

Mismanagement of carrying capacity often leads to an increase in woody species (Fig. 6) (Adamoli et al., 1990; Bucher and Huszar, 1999; Kunst et al., 2006). Woody encroachment has been described as a global phenomenon (Sala and Maestre, 2014), occurring at similar rates across different continents (0.1-1.1\% of cover/year) (Barger et al., 2011; Stevens et al., 2017), but faster in rangelands with high rainfall variability, as in the case of the Chaco, as the resulting lower predictability makes optimization of the carrying capacity more difficult (Kiage, 2013). Sedentary pastoralism (as opposed to transhumance strategies) has been mentioned as a sociological driver of rangeland degradation worldwide (Sayre et al., 2017). In the Dry Chaco rangelands, particularly in areas with limited bodies of water, sedentary pastoralism has been a predominant system across different scales of cattle ranching systems: smallholders in puestos, with the establishment of a ranch near a water body; and large scale producers with fences and different grazing managements. In addition, an increase of fire frequency from the 1970s and the resulting nitrogen volatilization (Archer and Predick, 2014) and increased atmospheric $\mathrm{CO}_{2}$ might also be drivers of the increase of woody cover (Grau et al., 2014).

With the aim of restoring herbaceous productivity, active woody encroachment controls such as prescribed fire and mechanical controls have been used in the region (Blanco et al., 2005; Kunst et al., 2012; Ledesma et al., 2018). These practices commonly include the seeding of exotic C4 grasses: Megathyrsus maximum in the wettest areas, Pennisetum ciliare in the driest areas (Houspannosian et al., 2016), or Chloris gayana in halomorphic soils. Despite their similar physiological pathway (i.e., C4, as with many native grasses), exotic grasses often become dominants in basal cover, multiplying up to four times grassland productivity (Blanco et al., 2005; Kunst et al., 2012), but reducing biodiversity in the herbaceous community. This increase of productivity by a monodominant species implies a stronger phenological seasonality than multispecies natural grasslands leading to changes in ecosystem functionality and in some cases constituting "novel" ecosystems (Hobbs et al., 2009).

The consequences of the mentioned replacement for biogeochemical cycles and biological interactions are understudied but potentially important aspects that should be addressed. For example, Macchi et al. (2013) found characteristic bird assemblages in natural grasslands that differed from that found in Megathyrsus pastures. However, the interaction of wild primary consumers (i.e., mammals and insects) needs to be much better understood. While carbon losses in soil storage by woody encroachment in natural grasslands and savannas are a process documented at global scale for rangelands (Eldridge et al., 2011), is a poorly understood process in the Chaco.

Ecosystem degradation or restoration are context specific and non-linear processes in rangelands, making difficult general management decisions. In contrast, adaptative management practices to restoring herbaceous productivity while maintaining a broad set of ecosystem services should be carried out contemplating differences in ecological sites, production systems and socioeconomic characteristics across different grasslands typologies of Dry Chaco.

State and transitions models plus the definition of ecological sites has been adopted in the northwest of Santiago del Estero province in Chaco region (Kunst et al., 2006) and should be considered as a promising framework for tackling rehabilitation of natural grasslands and savannas with less impacts in biodiversity while still maintaining social and economic values (Fig. 7). To make a regional assessment of the states of the grassland and savannas of the region, the map generated in this article (Fig. 1), in combination with soil maps and vegetation surveys and field validations, could be helpful in the evaluation of the state of degradation in different ecological sites of the region (Bestelmeyer et al., 2009). The next step should be to elucidate the management practices or the intrinsic conditions that drive the changes of states with respect to the references sites across the diversity of natural grassland and savanna types. Finally, it is necessary to monitor effects of restoration and management practices (including fire and mechanical woody control, and different stocking rates) on biodiversity and productivity. Participatory approaches among stakeholders could make a more effective and integrated assessing and monitoring regime for a large region such as the Dry Chaco, as occur in other regions as in United States rangelands where this approach is improving the capacity to make regional assessments (Bestelmeyer et al., 2017).

Conservation and restoration initiatives should also match with economic incentives for ranchers. Alternatives include subsides for meat or milk produced in these natural grasslands and savannas, tax reductions, certification schemes to facilitate ecosystem stewardship to conserve multiple ecosystem services while they are still being economically productive. The increase in the awareness of the variety of ecosystem services provided by these rangelands would help for the conservation of these ecosystems. For example, the partial replacement of montane grasslands by pine plantations in Cordoba province has been affecting the magnitude and temporal distribution of stream and river flows, with the water yield in afforested watersheds being $48 \%$ less than in 


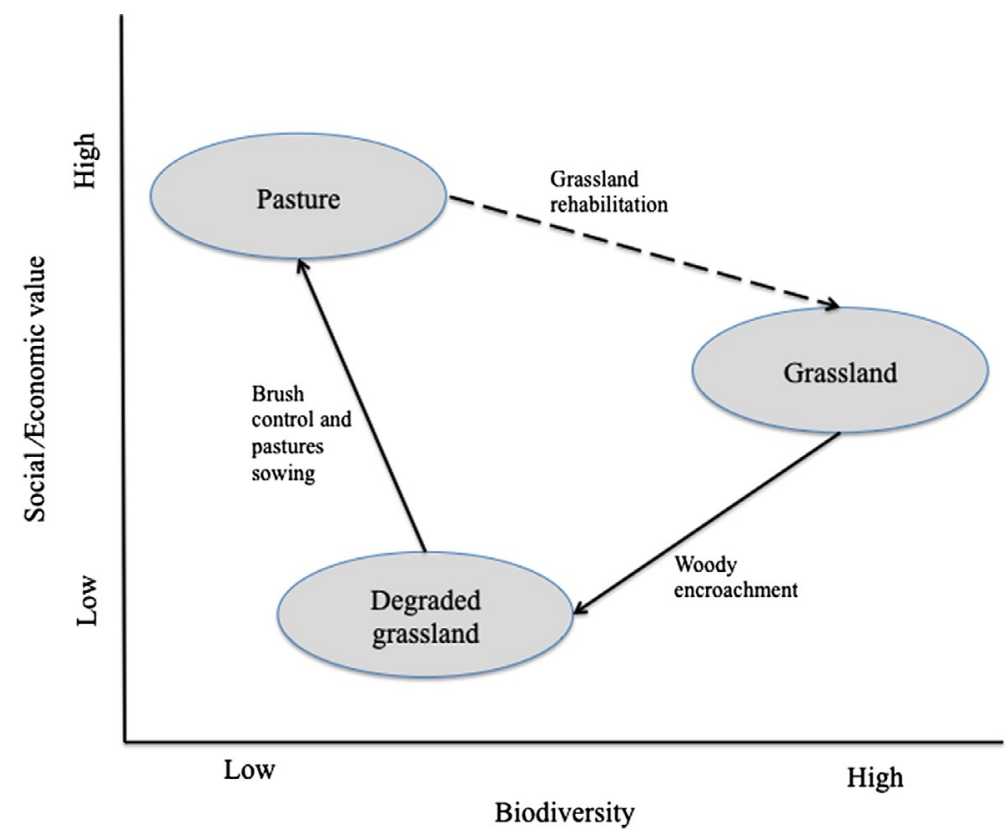

Fig. 7 The common transitions of natural grasslands in Dry Chaco and their relation with biodiversity and social economic value. In dotted lines is the unusual transition of rehabilitation.

grassland watersheds (Jobbágy et al., 2013). In the end, the principles of rangeland management would be more appropriately portrayed as those of the science of managing trade-offs among ecosystem services, and negotiating among stakeholders with competing interests. Thus, as Dry Chaco natural grasslands and savannas will become more valued as singular ecosystems and suppliers of broad ecosystems services for the society, interest on its research and conservation will increase (Fig. 7).

\section{Fire Regime}

Fire is one of the main disturbances in Dry Chaco grasslands and savannas. The fire regime (i.e., extent, frequency, severity and intensity) defines the role that fire plays in the ecosystem, affecting soil and plants. The fire season in Chaco region coincides with the prolonged dry season between April and October. Studies about historical fire regimes in grasslands and savannas of the region are scarce, due to the absence of fire records. However, paleo-environmental evidences suggest the natural occurrence of fire events at least over the last 4500 years, with fluctuations in their frequency and intensity related to climatic changes (Di Lello and Lindskoug, 2018; Linskoug, 2016).

Under current environmental conditions, grasslands and savannas dominated by natural grass can produce $1000-6000 \mathrm{~kg}$ $\mathrm{DM} \mathrm{ha}^{-1}$, depending on growing season rainfall. These loads of fine fuels can generate medium to high intensity fire events, with flame height reaching three meters (Kunst and Bravo, 2003). The positive association between fine fuel availability, fuel desiccation, and fire severity was confirmed in manipulative studies using experimental burns and controlled fine fuel loads in Chaco environments (Bravo et al., 2014; Ledesma et al., 2018). Higher fine fuel loads, low moisture content, and higher temperatures during the end of the fire season generate more severe fires. Most fires are concentrated in open areas managed for livestock, where fires are intentionally set with the aims of promoting palatable grass regrowth and woody encroachment control. The ecosystem stresses of overgrazing, excessive use of fires (and a consequent nitrogen volatilization), and droughts facilitate woody encroachment with significant losses in biodiversity and forage productivity both for wild and domestic herbivores.

Historical dendroecology descriptions of fire regimes indicate that water availability in the previous growing season, and subsequent fuel desiccation, controlled fire frequency and extension and resulted in a mean fire interval (MFI) of 3.3 years over the 1925-2000 period with a significant increase in fire frequency from the 1970 decade, attributed to greater water availability at the regional level (Bravo et al., 2010). Before 1970, mean annual precipitation was $496 \mathrm{~mm}$ and MFI was 5.63 years. An increase in $\sim 100 \mathrm{~mm}$ above such mean annual precipitation reduced MFI to 2 years, and more extensive fires occurred. Other dendroecological studies using fire scar height as an indicator of fire severity indicate that fires were more severe after 1970, and fires scars in trees were identified up to $4.30 \mathrm{~m}$ heights (Bravo et al., 2001a,b). These historic data suggest a high frequency fire regime of medium to high severity occurring in the last several decades in the Dry Chaco.

Fires usually increase herbaceous species diversity in natural grasslands and savannas during the 3-4 years after fire, when natural grasslands and savannas gradually recover their initial biodiversity (Kunst et al., 2003). The date of fire occurrence can modify its effect on herbaceous biodiversity, due to pre and post fire environmental conditions and species phenological status. 
Experimental burns at the mid-fire season (June to July) generated higher diversity than during early (April to May) or late (October) fires, probably due to better post fire environmental conditions close to spring. Late experimental burns are usually of high severity; thus, prescribed burns at the mid-fire season could be desirable to restore herbaceous species diversity in Chaco natural grasslands and savannas.

Isolated trees of Aspidosperma quebracho-blanco, Prosopis nigra, Prosopis kuntzei, or small shrubby patches of Vachellia aroma, Schinus bumeloides and Celtis ehrenbergiana are scattered across these savannas. The effects of fires on the tree components of Chaco savannas depend on species adaptations and regeneration strategies. Traits such as bark thickness, bud bank size, and reproductive mature age determine woody species maintenance in savannas. For example, A. quebracho-blanco is one of the most fire-resistant tree species in Chaco savannas, due to its thick bark (Bravo et al., 2008). Fabaceae species such as Prosopis nigra, P. kuntzei, Vachellia aroma, and Schinus sp., among others, have an important aerial bud bank, which allows these species to resprout from aerial organs after lowintensity fire events. Certain species also exhibit buds in underground organs, and can thus reestablish after high-intensity fires through basal resprouts (Bravo et al., 2014; Ledesma et al., 2018). The maintenance of tree habits in these species depends on bark thickness increase rate, and on the fire intervals in natural grasslands or savannas (Bravo et al., 2018).

\section{Assessing the Role of Natural Grasslands in Cattle Grazing, and Exploring Sustainable Intensification Opportunities}

Assessing cattle stock rates that can graze in natural grassland and savannas is an initial step to design restoration processes on natural grasslands and savannas with lower impacts on ranchers' livelihoods. At a regional scale, natural grasslands and savannas do not seem to be crucial for cattle diet, since their currently extension is $\sim 20.000 \mathrm{~km}^{2}$ (less than $0.5 \%$ of the region). With an average productivity of $3500 \mathrm{~kg} \mathrm{ha}^{-1}$ year $^{-1}$ of DM, the total share of natural grasslands could be enough to feed 2 millions of animal unit equivalents ( $3600 \mathrm{~kg}$ of DM year ${ }^{-1}$.a.u. ${ }^{-1}$, this is an average of c. 1 cattle per hectare). This amount could be enough to satisfy the requirements of $15 \%$ of the total stock of the entire Dry Chaco (around 12 million of cattle heads for Argentina, Paraguay and Bolivia). However, this rough number does not reflect diversity in herbaceous productivity or cattle management, and analyses at farm level could be key to understanding the role of these ecosystems in ranchers' livelihoods. In this section, we explore for the Argentinean Dry Chaco, the stocking rate of natural grasslands and savannas and simulate different scenarios of beef production exploring the possibility of sustainable intensification of cattle ranching.

\section{Cattle Grazing in Natural Grasslands and Savannas}

We estimate how much cattle can graze in natural grasslands and savannas, exploring the cattle density in these ecosystems for the Argentinean Dry Chaco (80\% of Dry Chaco natural grassland and savannas), where we have more detailed information. This rough estimate does not reflect the real current use by ranchers, the state of degradations, nor the role of natural grasslands in relation to other components of the productive system. To refine the analysis we selected $1 \times 1 \mathrm{~km}$ grid cells of the above-presented map (Fig. 1), with more than $50 \%$ of natural grassland share; and considered them as centers of a 3-km radius buffer for which we computed cattle stock using explicit geospatial cattle distribution data provided by foot and mouth disease vaccination of the Servicio Nacional de Sanidad y Calidad Alimentaria (SENASA) for 2017. Combining these data, we summed the potential maximum number of cattle heads that could be using natural grasslands and savannas as a forage source. Our results showed that near 720,000 cattle heads occur at less than $3-\mathrm{km}$ of radius for the total extension of $16,000 \mathrm{~km}^{2}$ of natural grassland and savannas in the Argentinean Dry Chaco (Fig. 8). This stock represents 13\% of the total stock for Argentine Dry Chaco.

\section{Assessing Potential for Cattle Intensification}

We also explored the possibilities for sustainable intensification (e.g., Garnett et al., 2013; Thomson et al., 2019) for cattle ranching. To do so, we performed dynamic simulations on 42 theoretical farms of cow-calf systems (i.e., productions systems oriented to production of calf to later finishing) across an extension of 14 millions of hectares with different landscape composition, soil (i.e., dominant texture) and climate, using a calibrated and evaluated biophysical cattle management model developed by Nasca et al. (2015). For each of these theoretical farms, we evaluated the following four scenarios in a gradient of intensity: M0 (baseline) cattle ranching developed on natural grasslands fodder sources with conventional management and low technological level; M1, which applies changes in cattle management (adjust of carrying capacity with climate variations, management of service in cows, strategic supplementation for rearing heifers, etc.), on the same landscape and fodder sources as M0; M2, which incorporate implanted pastures as fodder source, and includes same management as M1; and M3, equal to M2, but incorporating corn silage in cows diet. The interannual variability of carrying capacity of M0 was taken as the maximum acceptable threshold to select the outputs of M1, $\mathrm{M} 2$ and M3. For these, we carried out five simulations for each scenario modeled, selecting the one that fulfilled the highest productivity and less variability than M0.This condition was fundamental to evaluate resilient stocking rates through climatic variations.

In general, the results showed an increase in beef production (that range from $80 \%$ to $2000 \%$ ) in all scenarios in relation to the baseline (M0), indicating broad opportunities to increase beef production in Dry Chaco (Fig. 9). This increase varied across different edaphic-climatic conditions, showing the environmental constrain for beef production improvements. For example, the drops in beef production in M3 are explained by a dominance of sandy soils and consequent limitations to produce corn silage (Fig. 9). 


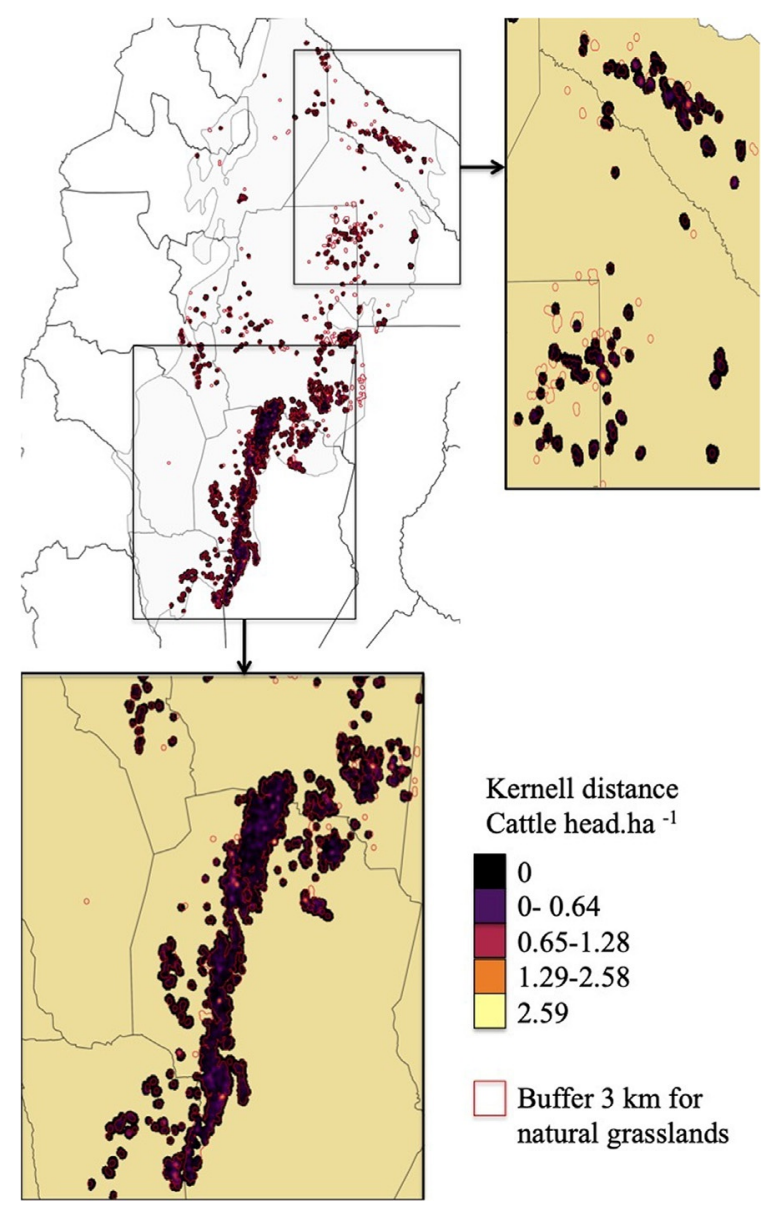

Fig. 8 Cattle density in natural grasslands and savannas of Argentinean Dry Chaco. Red limits represent the 3-km buffer area from the center of pixels with more $50 \%$ of natural grasslands; the gradient between black and yellow inside each buffer is a kernel distance representing density of cattle head ha ${ }^{-1}$.

In $\mathrm{M} 2$ scenario (which incorporate implanted pasture in their fodder resources) average beef production was 10 times higher than in $\mathrm{M} 0$; and 3 times higher than M1. The M3 scenario represents the higher productive potential in situations of increasing intensification, obtaining average increases of $3100 \%$ in relation to M2 (Fig. 9). In conclusion, sustainable intensification provides many opportunities for increase beef production in the Dry Chaco, across diverse edaphic-climatic conditions. As many of the cattle ranching production in the region occur at small production scales (i.e., $85 \%$ of producers and $50 \%$ of cattle stock remain in farms with less than 250 heads; INTA, IER, SENASA, 2016) conservation practices which include the exclusion of grazing for prolonged times could impact the subsistence of local farmers. We argue with these results that there exists a broad opportunity to increase beef production through management decision. Governmental initiatives targeting to conserve natural grasslands and savannas or forests in this region, should consider the implementation of processes that improve cattle ranching production, as long as they release pressure on natural environments.

\section{Livestock-Wildlife Interactions}

The Chaco hosts an important biological diversity (Bucher and Huszar, 1999; TNC et al., 2005), with around 500 species of birds, 150 species of mammals, 120 species of reptiles and around 100 of amphibians; in addition to 3400 plant species (TNC et al., 2005). It also has a long history of colonization, land-use changes and interactions with wildlife, from subsistence hunting by native people to more intensified practices that expanded in the last decades (Eva et al., 2004; Hoyos et al., 2013). The combination of these practices has resulted in the mentioned replacement of natural grasslands and woodlands with shrubs and eroded areas of bare soil (Baldi and Jobbágy, 2012). Thus, many species occupying the region are in fact mostly associated to open vegetation (Macchi et al., 2013; Marinaro et al., 2015; Torres et al., 2014). However, conservation strategies almost exclusively focus on forests conservation, to the point that protected areas include fire suppression as a management policy, with the consequent woody encroachment (Cardozo et al., 2011; Grau et al., 2014).

Medium-large mammal species of the Argentine Chaco are particularly sensitive to anthropogenic changes, and their sharp decline is mostly attributed to habitat loss and hunting pressure (Periago et al., 2015). Among these species, many seem to prefer 


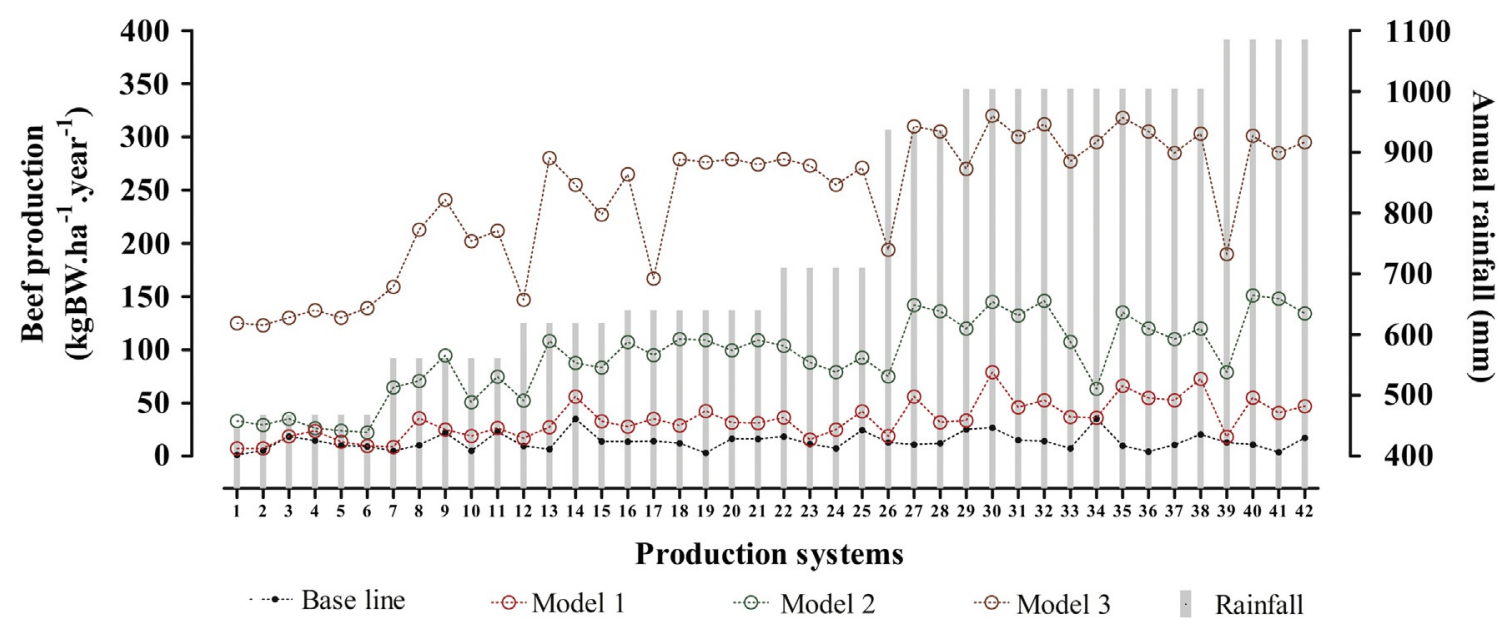

Fig. 9 Beef production ( $\mathrm{Kg} \mathrm{BW} \mathrm{ha}^{-1}$ year $^{-1}$ ) across annual rainfall gradient (gray bars) for different production systems and management scenarios. Base line: Scenario without management practices. Model 1: Scenario including adjusting carrying capacity. Model 2: Scenario including implanted pastures. Model 3:Scenario including corn silage supplementation.

open habitats (e.g., giant anteater, guanaco, manedwolf, large rhea) and their populations may thus be further threatened by forestcentered policies. Medium-large mammals play important, yet understudied functional roles in Chaco ecosystems (Periago et al., 2015). For example, preferential utilization of woody plants by wild browsers (Staver et al., 2009), or seed and seedling predators (Weltzin et al., 1997) may help maintain grassland and savanna communities. The behavior of these herbivores can prevent shrubs and trees from establishing and exerting dominance, and maintain them at a stature vulnerable to fire. On the contrary, woody plants may be in advantage where livestock are effective dispersers of their seeds. In addition, livestock introductions can cause displacement of native browsers and seed predators, releasing woody plants from top-down controls. Preserving populations of native herbivores in systems managed for livestock grazing may help maintain grass-woody populations in desired configurations, while concurrently enhancing biodiversity.

The introduction of cattle early in the 20th century not only affected the balance between woody and herbaceous cover, with several indirect effects on many species, but also gave place to other issues that threaten medium-large mammal communities, such as human-carnivore conflicts due to actual or perceived livestock depredation (Quiroga et al., 2014). The combined effect of traditional hunting and retaliatory/preventive hunting by livestock breeders has already caused the ecological extinction of jaguars in the Argentine Chaco (Quiroga et al., 2014) and is possibly behind the low population densities of the puma, the only other apex predator of the region (Quiroga et al., 2016). Because top-predators have strong top-down effects, the marked decrease in their populations in the Chaco may cause far-reaching changes in the dynamics of its ecosystems.

\section{Conservation and Representation in Protected Areas}

Human population is projected to increase from the current $\sim 7$ billion people, to $\sim 10$ billion people by 2050 (United Nations, 2017). This population growth, translated into an increasing global food demand, strongly threats natural areas worldwide; particularly in regions such as the Dry Chaco, with strong potential for agriculture expansion (Lambin et al., 2013). However, conservation policies have focused on the threats exerted to forests, at the extreme of neglecting natural grasslands as a specific, and fundamental conservation target (Grau et al., 2014). In addition, these policies may even result in increased pressure over nonforested landscapes, such as natural grasslands (Miles and Kapos, 2008).

The Dry Chaco ecoregion as a whole is rather under-protected. The protected area represents $11.1 \%$ of the entire ecoregion, with large differences among the three encompassed countries. Whereas $35.7 \%$ of the area is protected in the Bolivian Chaco, the Paraguayan and Argentine Chaco portions barely reach values of $11.8 \%$ and $4.8 \%$, respectively. In addition, forests mostly represent these percentages. In the Argentinean portion, only $4.1 \%$ of the protected area encompasses natural grasslands, while in Bolivia this value reaches only $0.18 \%$; and in Paraguay, $1.7 \%$. Regarding the relative extension of protected natural grasslands, only $10.1 \%$ of Argentine Dry Chaco natural grasslands are protected. In turn, Bolivian native grasslands are protected in a similarly low proportion $(9.8 \%)$, while in Paraguay this amount increases, with $16.5 \%$ of the natural grasslands under protection. We argue that natural grasslands need to be specifically targeted by biodiversity conservation planning, which is not the case in current forest-based initiatives.

Biodiversity in the region is likely very-well adapted to, and even dependent on, natural grasslands and savannas (Grau et al., 2014). Protected areas do not ensure grassland conservation; rather, fire suppression policies that favor woody encroachment are applied, which potentially leads to the disappearance of the grasslands with the highest conservation value (Cardozo et al., 2011). Further, the Native Forest Law of Argentina also ignores the importance of grasslands for many animal species, including species 
with high conservation concerns (Grau et al., 2014; Marinaro and Grau, 2015). Identify the "old-growth" natural grassland and savannas (i.e., ancient ecosystems characterized by high herbaceous species richness, high endemism, and unique species compositions) (Veldman et al., 2015) represent an urgent task to identify priority areas of conservation related to natural grasslands and savannas of different typologies.

\section{Future Research and Conclusions}

Natural grasslands and savannas are singular components of the Dry Chaco geography spread in different environments and diverse physiognomies, but during the last century they have been seriously reduced and transformed by different human activities that resulted in their replacement by both woody vegetation and agriculture. They have been neglected by the scientific community, in the understanding of their contribution to biodiversity and human livelihoods. Governments, on the other hand, neglected these ecosystems in terms of conservation and management policies. Albeit we elucidate that cattle stocking rates supported by natural grasslands and savannas, particularly in Argentine Chaco, would not represent a major obstacle in terms of production cost at regional scales, the impact of removing the cattle of such areas in terms of livelihoods and rural and indigenous populations' subsistence is not understood and has not been addressed to date. In addition, knowledge of the biological composition, ecological interactions and biogeochemical cycles of natural grassland and savannas transitions (novel ecosystems of implanted pastures, and encroached natural grasslands) should be intensified. The reintroduction of prescript fires not only as a production but also as a conservation tool, the alternatives of restoration practices, and the promotion of ecotourism as sources of income are alternatives whose costs and benefits should also be addressed. We believe that studies in this particular landscape are in initial stages and we encourage continuing understanding these singular ecosystems.

\section{References}

Adamoli J, Sennhauser E, Acero JM, and Rescia A (1990) Stress and disturbance: Vegetation dynamics in the Dry Chaco region of Argentina. Journal of Biogeography 17: 147-156. Anadon JD, Sala OE, Turner BL, and Bennett EM (2014) Effect of woody-plant encroachment on livestock production in North and South America. Proceedings of the National Academy of Sciences 111: 12948-12953. https://doi.org/10.1073/pnas.1320585111.

Archer S and Predick K (2014) An ecosystem services perspective on brush management: Research priorities for competing land use objectives. Journal of Ecology 102: $1394-1407$. Baldi G and Jobbágy EG (2012) Land use in the dry subtropics: Vegetation composition and production across contrasting human contexts. Journal of Arid Environments 76 : 115-127.

Maurice de Bunsen HE, Cunninghame Graham RB, Ewbank A, Evans JW, and Barbrooke Grubb W (1919) The Paraguayan Chaco and Its possible future. Discussion. The Geographical Journal 54: 171. https://doi.org/10.2307/1780057.

Barger NN, Archer SR, Campbell JL, Huang CY, Morton JA, and Knapp AK (2011) Woody plant proliferation in North American drylands: A synthesis of impacts on ecosystem carbon balance. Journal of Geophysical Research 116: G00K07.

Baumann M, Gasparri I, Piquer-Rodriguez M, Gavier-Pizarro G, Griffith P, Hostert P, and Kuemmerle T (2016) Carbon emissions from agricultural expansion and intensification in the Chaco carbon emissions from agricultural expansion and. Global Change Biology. https://doi.org/10.1111/gcb.13521.

Bestelmeyer BT, Tugel AJ, Peacock GL Jr., Robinett DG, Shaver PL, Brown JR, Herrick JE, Sanchez H, and Havstad KM (2009) State-and-transition models for heterogeneouslandscapes: A strategy for development and application. Rangeland Ecology \& Management 62: 1-15.

Bestelmeyer BT, Ash A, Brown JR, Bulgamaa Densambuu B, Fernández-Giménez M, Johanson J, Levi M, Lopez D, Peinetti R, Rumpff L, and Shaver P (2017) State and transition models: Theory, Applications, and challenges. In: Book rangeland systems. Springer.

Bishko JC (1952) The peninsular background of Latin American cattle ranching Linked references are available on JSTOR for this article. The Hispanic American Historical Review 32: $491-515$.

Blanco LJ, Ferrando CA, Biurrun FN, Orionte EL, Namur P, Recalde DJ, and Berone GD (2005) Vegetation responses to roller chopping and buffelgrass seeding in Argentina. Rangeland Ecology \& Management 58. https://doi.org/10.2111/1551-5028 (2005) 58.

Boletta PE (1988) Clima. Cap.1. In: Casas RR (ed.) Desmonte y habilitación de tierras en la Región Chaqueña semiárida. Red de Cooperación Técnica en el uso de los Recursos Naturales en la Región Chaqueña Semiárida, pp. 7-21. Santiago, Chile: FA0. pág.

Bravo S, Kunst C, Giménez A, and Moglia J (2001a) Fire regime of an Elionorus muticus Spreng. Savanna, western Chaco region, Argentina. International Journal of Wildland Fire 10: $65-72$.

Bravo S, Giménez A, and Moglia G (2001b) Efectos del fuego en la madera de Prosopis alba Griseb. y Prosopis nigra (Griseb.) Hieron, Mimosaceae. Bosque 22(1): 51-63.

Bravo S, Kunst C, and Grau H (2008) Suitability of the native woody species of the Chaco region, Argentina, for use in dendroecological studies of fire regimes. Dendrochronologia 26: 43-52.

Bravo S, Kunst C, Grau R, and Aráoz E (2010) Fire-rainfall relationship in Argentine Chaco savannas. Journal of Arid Environments 74: 1319-1323.

Bravo S, Kunst C, Leiva M, and Ledesma R (2014) Response of hardwood tree regeneration to surface fires, western Chaco region, Argentina. Forest Ecology and Managementt 326: $36-45$.

Bravo, S., N. Abdala, del Corro F., V. Ibáñez-Moro, A. Santacruz-García, D. Loto, F. Ojeda, 2018. Regeneración en especies de leñosas nativas del Chaco de Argentina y su respuesta a disturbios. En: Los Bosques y el Futuro, Consolidando un vínculo permanente en educación Forestal. A. Giménez and G. Bolzón (Eds.). Universidad Federal do Paraná/Universidad Nacional de Santiago del Estero. ISBN 978-987-1676-77-4

Bucher E (1982) Chaco and Caatinga e South American arid savannas, woodlands and tickets. In: Huntley B and Walker B (eds.) Ecology of tropical savannas, pp. 48-79. Germany: Springer Verlag.

Bucher EH and Huszar PC (1999) Sustainable management of the Gran Chaco of South America: Ecological promise and economic constraints. Journal of Environmental Management 57: 99-108. https://doi.org/10.1006/jema.1999.0290.

Burkart R, Barbaro N, Sanchez R0, and Gomez DA (1999) Ecoregiones de la Argentina. Buenos Aires: Secretaria de Ambiente y Desarrollo Sustentable-ANP.

Cabido M, Ateca N, Astegiano M, and Anton A (1997) Distribution of C3 and C4 grasses along an altitudinal gradient in Central Argentina. Journal of Biogeography 24(2): 197-204.

Cabido M, Funes G, Pucheta E, Vendramini F, and Diaz S (1998) A chorological analysis of the mountains from Central Argentina. Is all what we call Sierra Chaco really Chaco? Contribution to the study of the flora and vegetation of the Chaco. XII. Candollea 53: 321-331.

Cabido M, Zeballos SR, Zak M, Carranza ML, Giorgis MA, Cantero JJ, and Acosta ATR (2018) Native woody vegetation in central Argentina: Classification of Chaco and Espinal forests. Applied Vegetation Science 1-14. https://doi.org/10.1111/avsc.12369. 
Capitanelli R (1979) Geomorfología. In: Vazquez J, Miatello R, and Roque M (eds.) Geografía física de la provincia de Córdoba, pp. 45-138. Buenos Aires: Boldt. Cardozo S, Tálamo A, and Mohr F (2011) Composition, diversity, and structure of woody vegetation in two ancient watercourses with different human interventions in the semiarid Chaco of Argentina. Bosque 32(3): 279-286.

Di Lello M and Lindskoug H (2018) Fuegos del pasado. Escenarios ambientales arqueológicos e históricos en las Sierras Pampeanas a partir del análisis de microcarbones. VII Congreso Nacional de Arqueometría. Materialidad, Arqueología y Patrimonio. Centro de Investigaciones en Ecología Histórica. Facultad de Ciencias Naturales e Instituto Miguel Lillo, Universidad Nacional de Tucumán, Serie Monográfica y Didáctica vol. 56, 50-54. ISSN 03275868 (versión impresa).

Díaz S, Acosta A, and Cabido MR (1994) Community structure in montane grasslands of Central Argentina in relation to land use. Journal of Vegetation Science 5: 483-488.

Eldridge DJ, Bowker MA, Maestre FT, Roger E, Reynolds JF, and Whitford WG (2011) Impacts of shrub encroachment on ecosystem structure and functioning: Towards a global synthesis. Ecology Letters 14: 709-722. https://doi.org/10.1111/j.1461-0248.2011.01630.x.

Eva HD, Belward AS, De Miranda EE, Di Bella CM, Gond V, Huber 0, and Fritz S (2004) A land cover map of South America. Global Change Biology 10(5): $731-744$.

Garnett T, Appleby MC, Balmford A, Bateman IJ, Benton TG, Bloomer P, Burlingame B, Dawkins M, Dolan L, Fraser D, Herrero M, Hoffmann I, Smith P, Thornton PK, Toulmin C, Vermeulen SJ, and Godfray HC (2013) Sustainable intensification in agriculture: Premises and policies. Science (80-) 341: 33-34. https://doi.org/10.1126/science.1234485. Glatzle A (1999) Compendio para el Manejo de Pasturas en el Chaco. Paraguay: Editorial El Lector. Asunción214.

Grau HR, Gasparri Nl, and Aide TM (2005) Agriculture expansion and deforestation in seasonally dry forests of north-West Argentina. Environmental Conservation 32: 140. https://doi. org/10.1017/S0376892905002092.

Grau HR, Torres R, Gasparri NI, Blendinger PG, Marinaro S, and Macchi L (2014) Natural grasslands in the Chaco. A neglected ecosystem under threat by agriculture expansion and forest-oriented conservation policies. Journal of Arid Environments 123: 40-46.

Griffiths D (1904) Range investigations in Arizona. Washington, DC, USA: Government printing office. USDA Bureau of Plant Industry Bulletin No. 67. 62 p.

Herrera P, Torella S, and Adámoli J (2003) Los incendios forestales como modeladores del paisaje en la región chaqueña. In: Kunst C, Bravo S, and Panigatti J (eds.) Fuego en los Ecosistemas Argentinos, pp. 145-156. Argentina: Ediciones INTA

Hess SC, et al. (2007) Evaluation of seasonal changes in chemical composition and antibacterial activity. Quimica Nova 30(2): 370-373.

Hobbs RJ, Higgs E, and Harris JA (2009) Novel ecosystems: Implications for conservation and restoration. Trends in Ecology \& Evolution 24: 599-605. https://doi.org/10.1016/j. tree.2009.05.012.

Houspannosian J, Giménez R, Baldi G, and Nosetto M (2016) Is aridity restricting deforestation and land uses in the South American Dry Chaco? Journal of Land Use Science 4248. https://doi.org/10.1080/1747423X.2015.1136707.

Hoyos LE, Cingolani AM, Zak MR, Vaieretti MV, Gorla DE, and Cabido MR (2013) Deforestation and precipitation patterns in the arid Chaco forests of central Argentina. Applied Vegetation Science 16(2): 260-271. https://doi.org/10.1111/j.1654-109X.2012.01218.x.

INTA (1990) Instituto Nacional de Tecnología Agropecuaria. Estación Experimental Agropecuaria Rafaela. Carta de Suelos de la República Argentina. Hojas 3163-05 y 06. Villa Trinidad.

INTA, IER, SENASA (2016) Existencia, distribución y eficiencia de la producción bovina en el523 Chaco semiárido (0toño 2015).

Jobbágy EG, Acosta AM, and Nosetto MD (2013) Rendimiento hídrico en cuencas primarias bajo pastizales y plantaciones de pino de las sierras de Córdoba (Argentina). Ecología Austral 23(2): 87-96.

Jolis SJJ (ed.) (1972) Ensayo sobre la historia natural del Gran Chaco. Resistencia, Chaco: Universidad Nacional del Nordeste (Instituto de Historia)

Kiage LM (2013) Perspectives on the assumed causes of land degradation in the rangelands of Sub-Saharan Africa. Progress in Physical Geography 37: 664-684. https://doi.org/ $10.1177 / 0309133313492543$.

Killeen TJ, Guerra A, Calzada M, Correa L, Calderon V, Soria L, Quezada B, and Steininger MK (2008) Total historical land-use change in Eastern Bolivia: Who, where, when, and how much? Ecology and Society 13(1): 36

Kunst C and Bravo S (2003) Ecología y régimen de fuego en la región chaqueña argentina. In: Kunst C, Bravo S, and Panigatti J (eds.) Fuego en los Ecosistemas Argentinos, pp. 109-118. Argentina: Ediciones INTA.

Kunst C, Bravo S, Moscovich F, Herrera J, Godoy J, and Vélez S (2003) Fecha de aplicación de fuego y diversidad de herbáceas en una sabana de Elionorus muticus (Spreng) 0. Kuntze. Revista Chilena de Historia Natural 76: 105-115.

Kunst C, Monti E, Pérez H, and Godoy J (2006) Assessment of the rangelands of southwestern Santiago del Estero, Argentina, for grazing management and research. Journal of Environmental Management 80: 248-265. https://doi.org/10.1016/j.jenvman.2005.10.001.

Kunst C, Ledesma R, Bravo S, Albanesi A, Anriquez A, van Meer H, and Godoy J (2012) Disrupting woody steady states in the Chaco region (Argentina): Responses to combined disturbance treatments. Ecological Engineering 42: 42-53. https://doi.org/10.1016/j.ecoleng.2012.01.025.

Lamarque P, Tappeiner U, Turner C, Steinbacher M, Bardgett RD, Szukics U, Schermer M, and Lavorel S (2011) Stakeholder perceptions of grassland ecosystem services in relation to knowledge on soil fertility and biodiversity. Regional Environmental Change 11: 791-804. https://doi.org/10.1007/s10113-011-0214-0.

Lambin EF, Gibbs HK, Ferreira L, Grau R, Mayaux P, Meyfroidt P, Morton DC, Rudel TK, Gasparri I, and Munger J (2013) Estimating the world's potentially available cropland using a bottom-up approach. Global Environmental Change 23: 892-901. https://doi.org/10.1016/j.gloenvcha.2013.05.005.

Ledesma R, Kunst C, Bravo S, Leiva M, Lorea L, Godoy J, and Navarrete V (2018) Developing a prescription for brush control in the Chaco region, effects of combined treatments on the canopy of three native shrub species. Arid Land Research and Management. https://doi.org/10.1080/15324982.2018.1430072.

Linskoug H (2016) Forest fires and abandonment patterns from the Aguada culture, Northwest Argentina: A Paleoenvironmental Study Based on the Analysis of Microcharcoals in the Ambato Valley, Catamarca Province, 176 pp. Doctoral Thesis Argentina: Universidad Nacional de Córdoba.

Macchi L, Grau HR, Zelaya PV, and Marinaro S (2013) Trade-offs between land use intensity and avian biodiversity in the Dry Chaco of Argentina: A tale of two gradients. Agriculture Ecosystems \& Environment 174: 11-20.

Magliano PN, Murray F, Baldi G, Araud S, Paez R, Harder W, and Jobbagy EG (2015) Rainwater harvesting in Dry Chaco: Regional distribution and local water balance. Journal of Arid Environments 123: 93-102. https://doi.org/10.1016/j.jaridenv.2015.03.012.

Marinaro S and Grau RH (2015) Comparison of animal biodiversity in three livestock systems of open environments of the semi-arid Chaco of Argentina. The Rand Journal of Economics 37(5): 497-505

Marinaro S, Grau HR, Macchi L, and Zelaya PV (2015) Land tenure and biologicalcommunities in dry Chaco forests of northern Argentina. Journal of Arid Environments 123: 60-67.

Menghi M. Bertrán de Solís MA, Galera MF. Herrera MA, and Luti R (1978) Productividad primaria de los pastizales de altura de las Sierras Chicas. Córdoba. Ecología 3: 101-110.

Métraux A (1946) Ethnology of the Chaco. In: Steward J (ed.) Handbook of south American indians. Smithsonian Institution, Bulletin 143, Vol. 1, The marginal tribespp. 197-379. US Government Printing Office.. http://biodiversitylibrary.org/page/26734435.

Miles L and Kapos V (2008) Reducing greenhouse gas emissions from deforestation and Forest degradation: Global land-use implications. Science 1454(2008): 320. https://doi.org/ 10.1126/science.1155358.

Morello J and Saravia Toledo C (1959) El bosque Chaqueño. La ganadería y El bosque en el oriente de Salta. Revista Agronomica del Noroeste Argentino 3: 209-258.

Morello J, Pengue W, and Rodríguez A (2013) Un siglo de cambios de diseño del paisaje: el Chaco Argentino. Medio Ambiente y Urbanización 79(1): 25-64.

Moretti LM, Morrás HJM, Pereyra FX, and Schulz GA (2018) Soils of the Chaco Region. In: The Soils of Argentina. Springer.

Muello AC (ed.) (1926) Geografía económica del Chaco y Formosa. Buenos Aires: Oceana.

Nasca JA, Feldkamp CR, Arroquy Jl, and Colombatto D (2015) Efficiency and stability in subtropical beef cattle grazing systems in the northwest of Argentina. Agricultural Systems 133: 85-96. https://doi.org/10.1016/j.agsy.2014.10.014.

Navarro G and Fuentes A (1999) Geobotanica y sistemas ecológicos de paisaje en el gran Chaco de Bolivia. Revista Boliviana de Ecología y Conservación Ambiental 5: 25-50. 
Navarro G, Molina J, and de Molas LP (2006) Classification of the forests of the northern Paraguayan Chaco. Phytocoenologia 36: 473-508. https://doi.org/10.1127/0340-269X/ 2006/0036-0473.

Peel MC, Finlayson BL, and McMahon TA (2007) Updated world map of the Koppen-Geiger climate classification. Hydrology and Earth System Sciences 11: 1633-1644. https://doi. org/10.5194/hess-11-1633-2007.

Periago ME, Chillo V, and Ojeda RA (2015) Loss of mammalian species from the South American Gran Chaco: Empty savanna syndrome. Mammal Review 45(1): 41-53.

Quiroga VA, Boaglio Gl, Noss AJ, and Di Bitetti MS (2014) Critical population status of the jaguar Pantheraonca in the Argentine Chaco: Camera-trap surveys suggest recent collapse and imminent regional extinction. Oryx 48(1): 141-148.

Quiroga VA, Noss AJ, Paviolo A, Boaglio Gl, and Di Bitetti MS (2016) Puma density, habitat use and conflict with humans in the Argentine Chaco. Journal for Nature Conservation 31: $9-15$.

Sala OE and Maestre FT (2014) Grass-woodland transitions: Determinants and consequences for ecosystem functioning and provisioning of services. Journal of Ecology 102: 1357-1362. https://doi.org/10.1111/1365-2745.12326.

Sala 0 and Paruelo J (1997) Ecosystem services in grasslands. In: Daily GC (ed.) Nature's services: Societaldependence on natural ecosystems, pp. 237-251. Washington, D.C.: Island Press.

Sayre NF, Davis DK, Bestelmeyer B, and Williamson JC (2017) Rangelands: Where Anthromes Meet Their Limits. Land 6: 31. https://doi.org/10.3390/land6020031.

Smith JG (1899) Grazing problems in the Southwest and how to meet them, 46 p. Washington, DC, USA: Government Printing Office. USDA Division of Agrostology Bulletin No. 16.

Staver AC, Bond WJ, Stock WD, Van Rensburg SJ, and Waldram MS (2009) Browsing and fire interact to suppress tree density in an African savanna. Ecological Applications 19(7): 1909-1919.

Stevens N, Lehmann CER, Murphy BP, and Durigan G (2017) Savanna woody encroachment is widespread across three continents. Glob. Chang. Biol. 23: 235-244. https://doi.org/ $10.1111 /$ gcb. 13409 .

The Nature Conservancy, Fundación Vida Silvestre Argentina, Fundación para el Desarrollo Sustentable del Chaco, Wildlife Conservation Society Bolivia (2005) Evaluación Ecoregional del Gran Chaco Americano (Gran Chaco Americano EcoregionalAssessment). .

Thomson AM, Ellis EC, Grau HR, Kuemmerle T, Meyfroidt P, Ramankutty N, and Zeleke G (2019) Sustainable intensification in land systems: trade-offs, scales, and contexts. Current Opinion in Environment Sustainability 38: 37-43. https://doi.org/10.1016/j.cosust.2019.04.011.

Torres R, Gasparri NI, Blendinger PG, and Grau HR (2014) Land-use and land-cover effects on regional biodiversity distribution in a subtropical dry forest: a hierarchical integrative multi-taxa study. Regional Environmental Change 14(4): 1549-1561.

United Nations (2017) World population prospects: the 2017 revision, key findings and advance tables. In: ESA/P/WP/248, Department of EConomic and Social Affairs. New York: Population Division.

Veldman JW, Buisson E, Durigan G, Fernandes GW, Le Stradic S, Mahy G, Negreiros D, Overbeck GE, Veldman RG, Zaloumis NP, Putz FE, and Bond WJ (2015) Toward an old-growth concept for grasslands, savannas, and woodlands. Frontiers in Ecology and the Environment 13(3): 154-162. https://doi.org/10.1890/140270.

von Wehrden H, Hanspach J, Kaczensky P, Fischer J, and Wesche K (2012) Global assessment of the non-equilibrium concept in rangelands. Ecological Applications 22(2): 393-399.

Weltzin JF, Archer S, and Heitschmidt RK (1997) Small-mammal regulation of vegetation structure in a temperate savanna. Ecology 78(3): 751-763.

Wooton EO (1908) The range problem in New Mexico, 46 p. Albuquerque, NM, USA: New Mexico College of Agriculture and Mechanic Arts Agricultural Experiment Station. Albuquerque Morning Journal. Bulletin No. 66. 